green ; facial quadrangle a little longer than wide, the inner orbits convex; labrum (except very narrow margin and two large spots at basal corners), clypeus (except very narrow anterior edge and a long black mark on each lateral margin), supraclypeal band, rose-thorn-shaped lateral face-marks, and broad stripe on scape, all very pale yellow; hair of head, thorax, legs, and first two abdominal segments abundant, long, erect, and white, with no black hairs intermixed; flagellum entirely black; third antennal joint long and narrow, suddenly enlarging; trumpet-like, at the apex; thorax dull, densely rugoso-punctate; tegulæ black. Wings clear, nervures black or almost so. Legs black, even to the tarsi ; hair on inner side of tarsi shining coppery red when seen in the proper light; middle tarsi long and slender, twice as long as their tibiæ, but not otherwise peculiar; spurs very long; basal joint of hind tarsi with a prominent oblique tooth on the anterior margin; abdominal segments 3 to 5 with erect black hair, and some light hairs intermixed ; sixth with light hair, not conspicuous; no hair-bands; apical dorsal segment with short appressed silvery hair, narrowly truncate, with lateral margins showing a strong double curve; claspers very large, deeply bifid or bidentate, the posterior margin obtusely angled, the base of each posterior tooth emitting a long cylindrical light brown fleshy organ, beset with short hairs; ventral surface of abdomen with long white hair.

Hab. Las Vegas, N. M., May 7, 1903 (Anna Gohrman). Flying around Ribes longiflorum (along with A. Porterce), but the tongue seems too short to suck from that flower. It is allied to $A$. Edwardsii, Cresson.

XLIV.-Notes on South-American Monkeys, Bats, Carnivores, and Rodents, with Descriptions of new Species. By OldField Thomas.

The Generic Names Callithrix and Hapale.

THE common laxity about nomenclature is nowhere more striking than among the Primates, and an instance of this occurs in connexion with the genera of Cebidæ usually termed Callithrix and Hapale, the Titi Monkeys and Marmosets.

Fine paper as it was, Geoffroy's 1812 monograph of the 
monkeys * has had an unfortunate effect so far as nomenclature is concerned owing to its very excellence, for later authors have accepted his names, new or old, without enquiry, with results that now prove to need much revision.

Firstly, Callithrix, quoted quite commonly as from this paper, and consequently used for the Titis, was really first founded in 1777 by Erxleben, who included in it six monkeys, no one of which was a Titi ; and it is therefore quite evident that some other name must be used for this group. Thanks to the labours of Lesson, Gray, and others, names are numerous among South-American monkeys, but, curiously enough, I can find none that has ever been applied to the Titis except this untenable Callithrix and the misapplied "Saguinus, Lacépède," of Lesson, whose real basis was the common marmoset.

The Titi Monkeys will therefore need a new name, and Callicebus may be suggested for them, with $C$. personatus, Geoff., as the type species.

Passing to the Marmosets, we find that authors have been contented to use Illiger's Hapale of 1811 for them, ignoring the fact that no less than three earlier names exist, namely: Callithrix, Erxleben, 1777; Sagoinus, Kerr, 1792; and Sagouin, Lacérède, 1799.

Callithrix, Erxleben, contains six species-C. pithecia and five Marmosets. The first-named of these was made the type of the genus Pithecia by Geoffroy in 1812, now therefore Pithecia pithecia, leaving the type to be found among the Marmosets. Fortunately this can be definitely fixed by the quctation of "Callithrix" as the first synonym of Callithrix jacchus, this species having therefore to be taken as the type under the rule recently published on the subject in 'Science' $\dagger$.

In the splitting of the Marmosets into two genera this allocation of the type is fortunate, for it makes Jacchus, Geoff. (type C.jacchus), a pure synonym of Callithrix, and leaves Midas, Geoff. (type M. midas), available for the "Tamarins," the Marmosets with long typically-formed lower canines and small incisors, the group to which the name has usually been applied.

Sagoinus, Kerr, 1792, containing exactly the same species as Erxleben's Callithrix, becomes a full synonym of it, and cannot be used for any part of the group. The name being

* "Tableau des Quadrumanes," Ann. Mus. xix. p. 85 (1812).

$\dagger$ 'Science,' xvi. p. 114\%(1902). 
based on Sagouin, a quoted synonym of C. jacchus, also indicates that species as its type.

Sagouin, Lacépède, had as its only species Sagouin jacchus, the type species of Callithrix, into whose synonymy it will therefore fall.

Hapale, Illiger, 1811, being put as a classical renaming of "Saguinus, Cuvier, Duméril, Lacépède," will equally have C. jacchus as its type.

These conclusions may be tabulated as follows:-

\section{Titi Monkeys.}

Callicebus, nom. nov.

Callithrix, Geoff. Ann. Mus. xix. p. 112 (1812), et auctorum plurimorum (nec Erxleben, 1777).

"Saguinus, Lac.," Lesson, Man. Mamm. p. 56 (1827) (nec Sagouin, Lac. 1799, nec “ Saguinus, Lac.," Illiger, 1811).

Type C.personatus, Geoff.

\section{True Marmosets.}

Callithrix, Erxl.

Callithrix, Erxl. Syst. R. A. p. 55 (1777).

Sagoinus, Kerr, Linn. An. K. p. 80 (1792).

Sagouin, Lacépède, Tabl. Mamm. (1799).

Hapale, Ill. Prodr. Syst., Mamm. p. 71 (1811).

Jacchus, E. Geoff. t. c. p. 118 (1812).

Type of all these names $C$.jacchus, Linn.

3. Tamarins.

Midas, Geoff.

Midas, Geoff. t. c. p. 120 (1812).

Type $M$. midas, Linn.

The family name for the Marmosets will be Callitrichidæ.

\section{Anthorhina picata, sp. n.}

General characters of A. longifolium, Wagn., with which it shares the comparatively uncrenulated state of the edgres of the lancet and other structural details, as described by Wagner and Peters. Margins of the long lancet and anterior edges of ears prominently bairy. Wings to the base of the metatarsus. Calcars shorter than in $A$. longifolium. 
Fur long, strictly limited to the body, except on the wingmembrane between the humerus and the flanks below; hairs of back about 8 millim. in length. General colour above very dark brown, something like "seal-brown" of Ridgway, but darker ; extreme bases of hairs whitish ; a prominent whitish dorsal streak running from the forehead to the root of the tail. Hairs on the bases of ears behind broadly and prominently white, so as to form a large showy white patch on each side of the crown. Sides of muzzle brown. Under surface and a line running up each side from the angle of the jaws to the hinder edge of the ears dirty yellowish white, the hairs dull slaty with yellowish tips.

Outer upper incisors and small anterior premolars subequal, the latter standing fairly in the tooth-row, not crowded out of it by the approximation behind them of the canine and large premolar, as is the case in A. crenulata.

Dimensions of the type (the measurements put in inverted commas taken in the flesh by the collector, the others on the dried skin) :-

Forearm 48 millim.

"Head and body $65 "$; " tail 22 "; " ear 27 "; noseleaf (dried) 15 ; tragus on inner edge 8 ; third finger, metacarpal 47 , first phalanx 14 , second phalanx 25.5 ; fifth finger, metacarpal 47 , first phalanx 11 , second phalanx 11 ; tibia 22.5 ; lower leg and foot (s. u.) 31 ; calcar 22. "Expanse 380."

Skull : greatest length 21.3 ; basal length 17 ; zygomatic breadth $12 \cdot 6$; constriction 4 ; mastoid breadth $12 \cdot 2$; front of canine to back of $m^{3} 8$.

Hab. Lamarão, Bahia. Alt. $300 \mathrm{~m}$.

Type. Adult male. Original number 1410. Collected 24th May, 1903, by Alphonse Robert.

This remarkable particoloured bat is evidently closely allied to the A. longifolium of Matto Grosso, but differs by the showy white ear-patches, the white (not "schmutzig grünlichgrau") dorsal streak, and the absence of any "rostgelb" colour on the throat and neck.

\section{LONCHOPHYLla, gen. nov. (Glossophagince).}

Interfemoral membrane large, the well-developed tail not reaching halfway to its edge in the middle line, terminating on its upper surface.

Skull elongate, with small brain-case, though not disproportionally so; zygomata undeveloped; pterygoids normal; 
palate not unduly elongate, no notches present on the outer sides of its posterior portion.

\section{Dentition :-}

$$
\text { I. } \frac{2}{2}, \text { C. } \frac{1}{1}, \text { P. } \frac{2}{3}, \text { M. } \frac{3}{3} \times 2=34 \text {. }
$$

Inner upper incisors conspicuously larger and longer than the outer ones, much thrown forward, broadly spatulate, close together, outer ones small, pointed, conical. Upper premolars and molars about as in Glossophaga, though markedly longer horizontally; last premolar with a well-defined internal lobe. Lower incisors not deciduous, more or less overlapping one another, broad, with sharp indistinctly trifid edges. Lower cheek-teeth long and narrow, not overlapping; with small gaps between the premolars.

Type L. mordax, sp. n.

This genus is no doubt nearly allied to Glossophaga, but may be distinguished by the absence of the zygomata and the unusual size and projection of the median upper incisors. From the development of these teeth and the size and persistence of the lower incisors it is evident that the tongue is less predominant at the expense of the incisors than is the case in the more specialized members of the group.

\section{Lonchophylla mordax, sp. n.}

General external appearance, so far as can be judged by skins, exactly as in Glossophaga soricina, except that the colour averages paler. The type is near "cinnamon-brown" above, the bases of the hairs whitish, and "wood-brown" below, but there is some variation in tone, and the darker specimens are quite as dark as the paler examples of Glossophaga obtained at the same place.

Chin apparently without the usual deep central groove, but as all the specimens are skins, with the skulls extracted, this point is not exactly determinable.

Ears rather more decidedly concave in the upper half of their outer margins than in Glossophaga. Noseleaf longer, the upper part of the lancet more sharply triangular, its sides evenly slanted, not concave. Proportions of limb-bones as shown by the measurements below. Size (apart from the very different length of head) and other characters as in Glossophaga.

Dimensions of the type (the measurements in inverted 
commas taken by the collector in the flesh, the others from the dried skin) :-

Forearm 34 millim. (all the specimens about the same).

"Head and body 55"; "tail 8"; " ear 13 "; lancet, measured behind (dried) $4 \cdot 8$; thumb (c. u.) 9 ; third finger, metacarpal 31, first phalanx $11 \cdot 3$, second phalanx 16.5 ; fifth finger, metacarpal 29 , first phalanx 8.5 , second phalanx 11 ; lower leg and hind foot (s. u.) 23 ; calcar 7.5. "Expanse 265."

Skull: greatest length 23.7 ; basal length 20.2 ; anterior breadth opposite $m^{1} 4 \cdot 8$; brain-case, breadth 9.5 ; palate length $12 \cdot 8$. Front of canine to back of $m^{1} 8 \cdot 1$; front of lower canine to back of $m_{3} 8 \cdot 7$.

Hab. Lamarão, N.W. of Bahia. Alt. $300 \mathrm{~m}$.

Type. Male. Original number 1552. Collected 3rd July, 1903, by Alphonse Robert. Eight specimens.

\section{Canis thous angulensis, subsp. $\mathrm{n}$.}

A small form of the $C$. thous * group, with short stoutly built skull, small flesh-tooth, and pale-coloured limbs.

Size smaller than in true $C$. thous or its Brazilian representative C.t.melampus $\dagger$. General colour much as in the latter, but even more strongly suffused with fulvous. Hairs of dorsal area elongated, annulated with black and white, and with broad black tips; hairs of sides similar but shorter. Underfur dull buffy, becoming ochraceous buff on the prominent postauricular patches. Under surface dirty buffy. Snout not blackened, scarcely darker than the forehead. Back of ears dark ochraceous buff, without blacker patches. Upper surface of hands and feet dull ochraceous buffy, with scarcely a trace of darker marking; below, the palms and soles are inconspicuously blackened. Tail bushy, coloured above like the dorsal area, below like the belly, its terminal hairs broadly black.

Skull very stoutly built, conspicuously shorter than in either thous or melampus. Forehead not markedly convex, the frontal region far flatter than in the allied forms. Palate

* Canis thous, Linn. Syst. Nat. (12) i. p. 60 (1766).

C. cancrivorus, Desm. Mamm. i. p. 199 (1820).

C. rudis, Günth. Ann. \& Mag. Nat. Hist. ser. 5, vol. iv. p. 400 (1879).

Type localities: Dutch, French, and British Guianas respectively.

† Wagn. Arch. f. Nat. 1843, p. 357.

C. brasiliensis, Lund, nec Cuv.

C. melanostomus, Wagn. l. c. 
ending opposite the middle of $\mathrm{m}^{2}$. Bullæ not particularly high.

Teeth small throughout, as shown by the measurements, the carnassials particularly small, smaller than in any other member of the group.

Dimensions of the type (measured in the flesh):-

Head and body 630 millim. ; tail 310 ; hind foot (s. u). 122 ; ear 68 .

Skull : greatest length in middle line 126 ; basal length 117 ; zygomatic breadth 73.5 ; nasals (from bottom of concavity in front) $41.5 \times 11.2$; interorbital breadth 28.5 ; across postorbital process 40 ; intertemporal breadth 31.5 ; breadth of brain-case 45.5 ; palate, length 62 , breadth across $m^{1} 39 \cdot 2$; horizontal length of $p^{4}$ (outside) 11, of $m^{1}$ and $m^{2}$ combined $14 \cdot 8$, of $m_{1} 13 \cdot 4$, of $m_{2} 7 \cdot 3$, of $m_{3} 4 \cdot 2$.

Hab. San Lourenço, near Pernambuco.

Type. Adult male. Original number 1654. Collected 6th August, 1903, by Alphonse Robert. Three specimens.

This little dog may be readily distinguished from its allies by its smali size, pale ears and feet, stout flat-fronted skull, and unusually small carnassials. In its cranial characters no approximation is shown towards it by the small delicately built Savannah race of $C$. thous described by me in $1901^{*}$; but, on the other hand, among examples of C.t. melampus from Lamarão, Bahia, one shows such resemblance to it as to render advisable its description as subspecies rather than species.

$\mathrm{Mr}$. Robert has been very successful in obtaining specimens of the present group of Canidæ, having sent home examples from Matto Grosso, Minas Geraes, São Paulo, Espirito Santo, and Bahia, and has been deservedly rewarded by the discovery of this distinct new race inhabiting the eastern angle of South America.

There appears to be no reason why Linnæus's name $C$. thous should have been always ignored in favour of Desmarest's $C$. cancrivorus, both coming from the same region. 'The large and widely distributed black-footed Brazilian form ought apparently to bear Wagner's appropriate name of C. t. melampus.

\section{Conepatus Huntii, sp. n.}

Most nearly allied to $C$. arequipce, Thos., with which it shares the considerable breadth of the white stripes and their

* C. thous savannarum. Described as C. cancrivorus savannarum, Ann. \& Mag. Nat. Hist. (7) viii. p. 146 (1901). 
termination on the loins. But anteriorly, instead of the median black stripe running forward, as is usual, to within half an inch of the black of the head, it ends on the withers 4 inches short of the coronal black, the whole breadth of the nape being therefore white, except for a minute and probably inconstant black spot halfway down the neck. Black of forehead liberally mixed with isolated white hairs. Tail almost entirely black; some isolated long white hairs on its middle third; the end wholly black.

Fur long, as usual in the highland species. Hairs from the coronal ridge to the isolated black spot directed forwards, those of the next two inches backwards; then those of the anterior inch of the median black stripe forwards, from a median radiating centre, behind which again all are directed backwards.

Skull rather shorter and broader than in C. arequipce.

Approximate dimensions of the type (measured on the skin) :-

Head and body (c.) 400 millim.; tail 250 ; hind foot, s. u. 62 , c. u. 69.

Skull: greatest length 77 ; basal length 66 ; zygomatic breadth 47 ; postorbital constriction 20.5 ; mastoid breadth 40 ; palate length 32 .

Hab. Caylloma, Peru. Altitude $4500 \mathrm{~m}$.

Type. Female. B.M. no. 3.8.4.1. Original number 30. Collected 18th January, 1903, and presented by Mr. Bernard Hunt.

"Shot crossing the pampa, with four or five others, about midday."-B. $H$.

This skunk is in some respects a link between C. arequipce and $C$. rex, but differs from both, as from all the other allied species, by its white nuchal region. I have named it in honour of its donor, to whom the National Museum is indebted for many excellent skins of Caylloma mammals.

\section{Galictis andina, sp. n.}

A member of the $G$. Allamandi group.

Size and general pattern of coloration as in G. Allamandi, but wherever in that animal the colour is white, notably on the light horizontal line bordering the black of the face and throat, in $G$. andina it is a dull buffy. Tips of dorsal hairs whitish buffy. Underfur of back and tail stronger buffy. The net result is that the whole animal has the buffy or 
yellowish suffusion characteristic of $G$. vittata, rather than the clear greyish of $G$. Allamandi.

Skull about as in $G$. Allamandi, smaller than in the large Brazilian form described by Nehring as $G$. crassidens. Nasals evenly narrowing backward and pointed behind, not abruptly narrowing from a broad point at about two thirds their length, as in the Central-American form. Last upper molar with a posteriorly broadened inner lobe, almost as in the Martens (Mustela), and in this respect quite unlike that of any other Galictis.

Dimensions of the type :-

Head and body 540 millim. ; tail 160 ; hind foot, s. u. 75 , c. u. 78 .

Skull : greatest length 85 ; basilar length 76 ; greatest breadth 49 ; interorbital breadth 19 ; mastoid breadth 46 ; palate length from gnathion 41 . 'Teeth: upper incisor-row 11 ; outer length of $p^{4} 9.5$; transverse length of $m^{1} 7 \cdot 8$; longitudinal diameter of inner lobe of $m^{1} 5 \cdot 1$; length of $m_{1} 10$.

Hab. Pozuzo, Peru.

Type. B.M. no. 3. 7. 14. 1. Collected 26th February, 1903, by W. Hoffmanns. Sexed as a male by collector.

'This Galictis differs both in colour and tooth-structure from the other members of the group. Its yellower colour is markedly different from that of two examples from Chiriqui (Watson) which I assign to $G$. Allamandi, and think also represent Nelson's G. canaster. Nehring's G. crassidens, on the other hand, appears to be a larger animal, as is shown by the greater dimensions of the teeth, and comes from a very different locality. Finally, the broadened inner lobe to the upper molar is quite unique in this genus and recalls the corresponding tooth in Galera.

\section{Sciurus Roberti, sp. n.}

An olive species related to $S$. Ingrami and gilvigularis.

Size, as gauged by linear measures, almost equal to that of $S$. Ingrami, but the animal is more lightly built, and the hands and feet in particular are markedly more slender. Fur throughout much shorter than in Ingrami, more as in gilvigularis (hairs of back only 6-7 millim. in length), that of ears, feet, and tail all shortened, in agreement with that of the body. General colour above olivaceous, varying from yellowish olivaceous to greyish. Under surface not sharply defined, white or whitish on the throat, inner sides of limbs, 
and belly, creamy buff varying to buffy white on the chest. Ears short-haired, without trace of fringes, their backs slightly more fulvous than the general colour. Upper surface of hands and feet generally becoming more fulvous terminally. Tail comparatively narrow, its breadth across the outstretched hairs not or scarcely exceeding 2 inches, its colour blackish washed with white, the two basal light rings of the hairs fulvous, but these are quite hidden by the broad black subterminal and white terminal bands; below they show more, so that the colour is there grizzled fulvous mesially, edged sublaterally with black and laterally with white. Mammæ 8.

Dimensions of the type (measured in the flesh):-

Head and body 175 millim.; tail 172 ; hind foot, s. u. 44, c. u. $47 \cdot 5$; ear 20 .

Skull : greatest length 46 millim.

Hab. S. Lourenço, near Pernambuco. Alt. $50 \mathrm{~m}$.

Type. Adult male. Original number 1613. Collected 29th July, 1903, by Alphonse Robert. Twelve specimens.

This squirrel evidently represents in the north-eastern corner of South America the S. Ingrami of Southern Brazil, of which Mr. Robert has collected a large series at localities ranging from Espirito Santo to Paraná.

In its general proportions it approaches the Amazonian S. gilvigularis, but differs from that and agrees with $S$. Ingrami by the much paler colour of its under surface. From $S$. Ingram $i$ in turn it may be distinguished by its shorter fur, unfringed ears, less bushy tail, the whiter instead of buffy colour of the inner sides of its limbs, and the white instead of yellow tipping to the caudal hairs.

Sciurus Ingrami was the first of the many discoveries made by Mr. Robert during his highly successful collecting tour in Brazil, and I have now had much pleasure in naming after him the present squirrel, its ally, obtained at the last locality worked by him before his return to Europe.

\section{A Special Genus for Dasyprocta acouchy.}

The long-tailed Agouti, "Dasyprocta" acouchy, Linn., is clearly a very different animal from all the ordinary members of Dasyprocta, and should, I think, be separated generically from them. Its main distinctive features are its welldeveloped tail and conspicuously smaller teeth, these latter being smaller, both relatively and absolutely, than in any species of Dasyprocta.

I would therefore propose to call it Myoprocta acouchy. 


\section{$2 \mathrm{BHL}$ Biodiversity Heritage Library}

Thomas, Oldfield. 1903. "XLIV.-_Notes on South-American monkeys, bats, carnivores, and rodents, with descriptions of new species." The Annals and magazine of natural history; zoology, botany, and geology 12, 455-464. https://doi.org/10.1080/00222930308678880.

View This Item Online: https://www.biodiversitylibrary.org/item/94944 DOI: https://doi.org/10.1080/00222930308678880

Permalink: https://www.biodiversitylibrary.org/partpdf/68424

\section{Holding Institution}

Harvard University, Museum of Comparative Zoology, Ernst Mayr Library

\section{Sponsored by}

Harvard University, Museum of Comparative Zoology, Ernst Mayr Library

\section{Copyright \& Reuse}

Copyright Status: Public domain. The BHL considers that this work is no longer under copyright protection.

This document was created from content at the Biodiversity Heritage Library, the world's largest open access digital library for biodiversity literature and archives. Visit BHL at https://www.biodiversitylibrary.org. 